\title{
Inheritance and Identification of a Major Quantitative Trait Locus (QTL) that Confers Resistance to Meloidogyne incognita and a Novel QTL for Plant Height in Sweet Sorghum
}

\author{
Karen R. Harris-Shultz, Richard F. Davis, Joseph E. Knoll, William Anderson, and Hongliang Wang
}

First, third, fourth, and fifth authors: U.S. Department of Agriculture-Agriculture Research Service (USDA-ARS), Crop Genetics and Breeding Research Unit, 115 Coastal Way, Tifton, GA 31793; and second author: USDA-ARS, Crop Protection and Management Research Unit, 2747 Davis Road, Tifton, GA 31793.

Accepted for publication 4 August 2015.

\begin{abstract}
Harris-Shultz, K. R., Davis, R. F., Knoll, J. E., Anderson, W., and Wang, H. 2015. Inheritance and identification of a major quantitative trait locus (QTL) that confers resistance to Meloidogyne incognita and a novel QTL for plant height in sweet sorghum. Phytopathology 105:1522-1528.

Southern root-knot nematodes (Meloidogyne incognita) are a pest on many economically important row crop and vegetable species and management relies on chemicals, plant resistance, and cultural practices such as crop rotation. Little is known about the inheritance of resistance to $M$. incognita or the genomic regions associated with resistance in sorghum (Sorghum bicolor). In this study, an $\mathrm{F}_{2}$ population $(n=130)$ was developed between the resistant sweet sorghum cultivar 'Honey Drip' and

of root. Strong correlations were observed between eggs per gram of root and total eggs, height and stalk weight, and between two measurements of Brix. Genotyping-by-sequencing was used to generate single nucleotide polymorphism markers. The G-Model, single marker analysis, interval mapping, and composite interval mapping were used to identify a major quantitative trait locus (QTL) on chromosome 3 for total eggs and eggs per gram of root. Furthermore, a new QTL for plant height was also discovered on chromosome 3. Simple sequence repeat markers were developed in the total eggs and eggs per gram of root QTL region and the markers flanking the resistance gene are 4.7 and $2.4 \mathrm{cM}$ away. These markers can be utilized to move the southern root-knot nematode resistance gene from Honey Drip to any sorghum line.
\end{abstract} the susceptible sweet cultivar 'Collier'. Each $\mathrm{F}_{2}$ plant was phenotyped for stalk weight, height, juice Brix, root weight, total eggs, and eggs per gram
Additional keyword: dominance.
Southern root-knot nematodes, Meloidogyne incognita, are distributed worldwide and parasitize thousands of plant species causing significant economic losses (Trudgill and Blok 2001). They are the most damaging pathogen of U.S. cotton (Gossypium hirsutum L.) (Blasingame and Patel 2013) and are also damaging on other crops including sugarbeet (Beta vulgaris L.) (Weiland and Yu 2003), tomato (Solanum lycopersicum L.) (Jacquet et al. 2005), bell pepper (Capsicum annuum L.) (Thies 2011), watermelon (Citrullus lanatus (Thunb.) Matsum. \& Nakai var. lanatus) (Davis 2007), melon (Cucumis melo L.) (Ploeg and Phillips 2001), okra (Abelmoschus esculentus L.) (Hussain et al. 2011), and soybean (Glycine max (L.) Merr.) (Herman et al. 1991). The use of methyl bromide, the fumigant most heavily relied upon for preplant soil treatment for vegetable and ornamental production for nearly 40 years to control nematodes, has been phased out under the Montreal Protocol because of its ability to deplete stratospheric ozone (Rosskopf et al. 2005). Management of parasitic nematodes without methyl bromide relies on nematicides, plant resistance, and cultural practices such as crop rotation (Zasada et al. 2010). For many plant species, the cultivars grown have no genetic resistance to $M$. incognita. Thus, nematicides and cultural practices are important for management in infested areas.

Continuous cropping of susceptible crop species can increase nematode populations. Commercial corn (Zea mays L.) hybrids allow significant reproduction of $M$. incognita (Davis and Timper 2000), which may reduce yields of subsequent susceptible crops

Corresponding author: K. R. Harris-Shultz;

E-mail address: Karen.Harris@ars.usda.gov

http://dx.doi.org/10.1094/PHYTO-06-15-0136-R

This article is in the public domain and not copyrightable. It may be freely reprinted with customary crediting of the source. The American Phytopathological Society, 2015. such as cotton (Windham 1998). However, crop rotation can be used for nematode control by separating the nematode from an effective host for a sufficient length of time to keep damaging population levels from developing (Zasada et al. 2010).

Reproduction of $M$. incognita on sorghum ranges from very low to very high. In a greenhouse study, 23 sorghum varieties infected with $M$. incognita race 3 showed that all varieties were capable of sustaining or increasing nematode populations and all were better hosts than cotton (McClure et al. 1998). Another study examined densities of $M$. incognita following summer crops of tropical corn and sorghum. For two of the sorghum cultivars, population densities of root-knot nematodes were lower compared with corn, yet for one sorghum cultivar densities were higher (McSorley and Gallaher 1993). Thus, sorghum can be an effective rotation crop for keeping root-knot nematode populations low, but cultivar choice is paramount.

In a previous study, sweet sorghum lines with high resistance or susceptibility to root knot nematode were identified (Davis and Anderson 2012). 'Honey Drip' was consistently resistant with 156 eggs per gram of root and 'Collier' was consistently susceptible with 8,689 eggs per gram of root. In this study, we sought to determine the inheritance of $M$. incognita resistance in the sorghum cultivar Honey Drip and to identify genomic regions associated with resistance. This information will allow breeders to move the resistance gene into any sorghum line and thus keep root-knot nematode populations low for the next susceptible crop.

\section{MATERIALS AND METHODS}

Development of an $F_{2}$ population segregating for root-knot nematode resistance. In a greenhouse, the resistant sorghum cultivar, Honey Drip (PI 641821), was crossed to the susceptible 
sorghum cultivar, Collier (PI 641862), by hand emasculation of Honey Drip and subsequent pollination with Collier. The resulting seeds were grown to the seedling stage and genotyped using four informative simple sequence repeat (SSR) markers, txp 10, txp 265, txp 289, and txp 65 (Casa et al. 2008) to identify $F_{1}$ plants. The polymerase chain reaction $(\mathrm{PCR})$ protocol $\left(\mathrm{Ta}=50^{\circ} \mathrm{C}\right)$ and gel running conditions have been previously described (Harris-Shultz et al. 2015). Confirmed $F_{1}$ plants were selfed, and a single $F_{1}$ plant was used to create the $\mathrm{F}_{2}$ mapping population.

Phenotyping the $\mathbf{F}_{2}$ plants. Twenty-two plants of Honey Drip, 12 plants of Collier, $14 \mathrm{~F}_{1}$ plants (which were confirmed by genotyping using markers txp 10 [Casa et al. 2008] and txp 482 [Murray et al. 2009] at the seedling stage), and $130 \mathrm{~F}_{2}$ plants were grown in a greenhouse in pots containing approximately $1.5 \mathrm{dm}^{3}$ of steam-pasteurized field soil (Tifton loamy sand; $83 \%$ sand, $9 \%$ silt, $7 \%$ clay, and $<1 \%$ organic matter). M. incognita was produced on eggplant roots (Solanum melongena L.), and second-stage juveniles (J2) were collected in a mist chamber for use as inoculum. When the sorghum plants were 28 days old, inoculum consisting of 4,000 $\mathrm{J} 2 /$ pot was distributed into two holes (approximately $2.5 \mathrm{~cm}$ deep) and covered with soil. Pots were watered immediately following inoculation. Nematode eggs were extracted from all sorghum roots in a pot 56 days after inoculation. Roots were washed free of soil, weighed, cut into $5-\mathrm{cm}$ pieces, and agitated in a $1 \%$ sodium hypochlorite solution for 4 min (Hussey and Barker 1973). Eggs were collected on nested 150 - over 25 - $\mu \mathrm{m}$ pore sieves and rinsed with tap water. A subsample was counted and the total number of eggs recovered from each pot was calculated. At the termination of the experiment, the stem of each plant was cut at the surface of the soil, the leaves were removed, and the youngest leaves were kept for DNA extraction. Stalk weight, height, Brix 1 (lower three internodes of the stem), and Brix 2 (upper internodes of the stem) were measured immediately after harvest.

Juice was extracted from the stalks by crushing, and then juicedissolved solids (Brix) were measured using a digital refractometer (Refracto 30GS, Mettler-Toledo, Schwerzenbach, Switzerland) and are reported in degrees Brix. One degree Brix $\left({ }^{\circ} \mathrm{Bx}\right)$ is equivalent to $1 \mathrm{~g}$ of sucrose in $100 \mathrm{~g}$ of solution and is commonly used as an approximation of the sugar content of sweet sorghum or sugarcane (Saccharum spp.) juice. A Pearson correlation between all measured traits was calculated using Excel 2010 (Microsoft Corp, Redmond, WA).

DNA extraction. DNA was extracted from Honey Drip, Collier, the $F_{1}$ plants, and $130 \mathrm{~F}_{2}$ plants using a GeneJET Plant Genomic DNA Purification Kit (Thermo Fisher Scientific, Waltham, MA). The $F_{2}$ plants were selected for genotyping-by-sequencing (GBS) based on total eggs, including $46 \mathrm{~F}_{2}$ plants with the highest total eggs and $46 \mathrm{~F}_{2}$ plants with the lowest total eggs from the $130 \mathrm{~F}_{2}$ plants. For these $92 \mathrm{~F}_{2}$ samples, $1 \mu \mathrm{l}$ of RNAse (Thermo Fisher Scientific) was added to each sample and then incubated at room temperature for $2 \mathrm{~h}$. DNA from the $\mathrm{F}_{2}$ plants, Honey Drip, Collier, and an $F_{1}$, were mailed to the Cornell University Genomic Diversity Facility (Ithaca, NY) for GBS (Elshire et al. 2011), bioinformatics, and alignment of the single nucleotide polymorphism (SNP) markers to the sorghum reference sequence (Sorghum bicolor assembly v. 2.1; Goodstein et al. 2012). For the GBS library construction, DNA was digested using the enzyme ApeKI.

Data analysis. SNP genotype calls and the alignment of the SNPs to the sorghum physical map were obtained from Cornell University. SNPs that were heterozygous in the parents were excluded from the analysis. The G-Model software (Bernardo 2013) was obtained from R. Bernardo, University of Minnesota. Marker data were coded as ' -1 ' (Collier) and ' 1 ' (Honey Drip) for each parental allele and ' 0 ' for the heterozygote. Significance level for the marker effect was 0.0001 as recommended (Bernardo 2013). $F_{2}$ phenotypic data that were not normally distributed (total eggs, eggs per gram of root) were log-transformed using $\log _{10}(x+1)$.
To use the JMP Genomics 6.1 software package (SAS Institute, Cary, NC), polymorphic SNP data used for the G-Model were recoded as ' 0 ' for the Honey Drip allele, ' 2 ' for the Collier allele, and ' 1 ' for a heterozygote. The Subset and Reorder Genetic Data feature was used to remove $\mathrm{F}_{2}$ plants with more than $25 \%$ missing data. SNP markers were removed if the minor allele frequency was less than $5 \%$ or if missing data were greater than $10 \%$. To examine the effect of removing $\mathrm{F}_{2}$ plants due to missing data on the number of QTL identified, single marker-analysis was run multiple times using data created using 5\% increments from $70 \%$ of nonmissing genotypes $\left(90 \mathrm{~F}_{2}\right.$ plants) to $85 \%$ nonmissing genotypes $\left(84 \mathrm{~F}_{2}\right.$ plants).

QTL mapping for traits total eggs, eggs per gram of root, root weight, height, stalk weight, Brix 1 , and Brix 2 using $91 \mathrm{~F}_{2}$ plants was accomplished in JMP Genomics 7.0 (SAS Institute) by first assigning SNPs to linkage groups using interactive hierarchical clustering and reducing the number of markers by K-means clustering (automated radius K-means). Next, markers were ordered on each linkage group by using the Haldane mapping function and the map order optimization algorithm. Linkage groups were broken if adjacent markers were greater than $35 \mathrm{cM}$. A QTL genotype probability set was created and interval mapping and composite interval mapping (control marker number $=5$; test window size $=10 \mathrm{cM}$ ) using an expectation maximization (EM) algorithm was used. QTLs were noted that had LOD scores of 4 or above and 1-LOD support intervals were used. The percentage of phenotypic variance explained by a QTL was calculated by multiplying the $R^{2}$ by 100 .

Creation of SSR markers for total eggs and eggs per gram of root QTL region. The chromosome 3 region from $52,682,672$ to $56,144,986$ bp in the NC_012872 sequence (whole genome shotgun sequence) was downloaded from GenBank. SSR markers were identified using SSRIT (Temnykh et al. 2001), and Primer3 (Rozen and Skaletsky 1998) was used to create primer pairs. PCR, as previously described, was performed on the parents, an $\mathrm{F}_{1}$, and all $130 \mathrm{~F}_{2}$ progeny. Joinmap v. 4 (Kyazma B.V., Wageningen, the Netherlands) was used to order the SSR markers with the rootknot nematode resistance gene.

\section{RESULTS}

Correlation among phenotypic traits. Seven traits (stalk weight, height, Brix 1, Brix 2, root weight, total eggs, and total eggs per gram of root) were measured for all $130 \mathrm{~F}_{2}$ plants. A very strong correlation (following the Dancey and Reidy 2004 categorization) was seen between eggs per gram of root and total eggs (Table $1 ; r=$ 0.943). A strong correlation was seen between height and stalk weight and between Brix 1 and Brix 2 (Table 1). Moderate correlations were seen between Brix 1 and stalk weight, Brix 2 and stalk weight, root weight and stalk weight, Brix 1 and height, Brix 2 and height, root weight and Brix 1, and root weight and Brix 2 (Table 1). Root weight and total eggs were weakly correlated.

Classification and segregation of resistance. Total eggs. Total eggs for the resistant parent, Honey Drip, ranged from 0 to 900 eggs, for the susceptible parent, Collier, ranged from 25,200 to 156,900 eggs, and the $F_{1}$ plants ranged from 0 to 3,000 eggs. The $\mathrm{F}_{2}$ plants ranged from 0 to 147,300 eggs. The frequency distribution for total eggs is shown (Fig. 1A). The total eggs $F_{2}$ data displayed a nonnormal distribution (skewness $=2.76$, kurtosis $=7.59$ ) with individuals skewed toward the resistant parent. Using a cutoff of greater than 5,000 eggs for susceptibility (4,000 second-stage juveniles were initially inoculated), $94 \mathrm{~F}_{2}$ plants were resistant and $36 \mathrm{~F}_{2}$ plants were susceptible. A $\chi^{2}$ test was used to test the goodness of fit to a 3:1 ratio, assuming a single dominant gene restricts total eggs, and supports a single dominant gene $\left(\chi^{2}=0.503, \mathrm{df}=1, P=0.4784\right)$. Alternatively, if using the mean and standard deviation of total eggs for susceptible cultivar Collier (average $=60,875$; standard deviation $=41,993$ ) to 
determine a threshold, 18,882 eggs would be the lower boundary for determining susceptibility. In this case, $104 \mathrm{~F}_{2}$ plants were resistant and $26 \mathrm{~F}_{2}$ plants were susceptible. A $\chi^{2}$ test was used to test the goodness of fit to a 3:1 ratio, assuming a single dominant gene restricts total eggs and supports a single dominant gene $\left(\chi^{2}=\right.$ 1.733 , df $=1, P=0.1880$ ).

Eggs per gram of root. Eggs per gram of root ranged from 0 to 37 for Honey Drip, 843 to 4,574 for Collier, and 0 to 133 for the $F_{1}$ plants. The frequency distribution of the $\mathrm{F}_{2}$ plants was not normal ( skewness $=2.32$; kurtosis $=5.41$ ) and was skewed toward the resistant parent (Fig. 1B). Using the mean and standard deviation of eggs per gram of root from Collier (average $=1,797$; standard deviation $=1,351$ ) to determine the threshold of susceptibility, 446 eggs per gram of root was used as the lower boundary of susceptibility. Thus, $97 \mathrm{~F}_{2}$ plants were resistant and $33 \mathrm{~F}_{2}$ plants were susceptible. A $\chi^{2}$ test supports that a single dominant gene restricts the number of eggs per gram of $\operatorname{root}\left(\chi^{2}=0.010, \mathrm{df}=1, P=0.9193\right)$.
Root weight. Using a $t$ test, root weight was significantly different $(t=3.05, \mathrm{df}=26, P=0.003)$ between Honey Drip (average $=$ $26.6 \mathrm{~g}$ ) and Collier (average $=35.7 \mathrm{~g}$ ). Honey Drip plants ranged from 9.8 to $46.7 \mathrm{~g}$ of root, Collier plants ranged from 25.9 to $51.1 \mathrm{~g}$ of root, and the $\mathrm{F}_{1}$ plants ranged from 17.2 to $52.3 \mathrm{~g}$ of root with an average value of $29 \mathrm{~g}$ of root. The frequency distribution of the $\mathrm{F}_{2}$ data (Fig. 1C) showed a normal distribution (kurtosis $=0.19$; skewness $=0.72$ ). This suggests that root weight is quantitatively inherited in this population.

Height. Using a $t$ test, stem height was significantly different $(t=$ 9.41, df $=32, P=4.95 \times 10^{-11}$ ) between Honey Drip (average $=$ $108 \mathrm{~cm}$ ) and Collier (average $=142 \mathrm{~cm}$ ). The average height for the $F_{1}$ plants was $127 \mathrm{~cm}$. The frequency distribution of the $F_{2}$ plants for height formed a normal distribution (kurtosis $=1.07$; skewness $=$ -0.86 ), suggesting many genes contribute to height (Fig. 1D).

Stalk weight. Using a $t$ test, stalk weight was not significantly different $(t=-1.02$, df $=31, P=0.16)$ between Honey Drip

TABLE 1. Pearson's correlation coefficients between each of the seven phenotypic traits measured on 130 Honey Drip $\times$ Collier $F_{2}$ plants ${ }^{\mathrm{a}}$

\begin{tabular}{|c|c|c|c|c|c|c|c|}
\hline Traits & Stalk weight & Height & Brix 1 & Brix 2 & Root weight & Egg number & Egg/root \\
\hline Stalk weight & - & & & & & & \\
\hline Height & $0.708 * *$ & - & & & & & \\
\hline Brix 1 & $0.677 * *$ & $0.434 * *$ & - & & & & \\
\hline Brix 2 & $0.661 * *$ & $0.502 * *$ & $0.869 * *$ & - & & & \\
\hline Root weight & $0.630 * *$ & $0.308 * *$ & $0.502 * *$ & $0.452 * *$ & - & & \\
\hline Egg number & $0.175^{*}$ & -0.024 & $0.193^{*}$ & 0.170 & $0.291 * *$ & - & \\
\hline Egg/root & 0.051 & -0.094 & 0.078 & 0.062 & 0.136 & $0.943 * *$ & - \\
\hline
\end{tabular}

a $* * P<0.01, * P<0.05$.

A

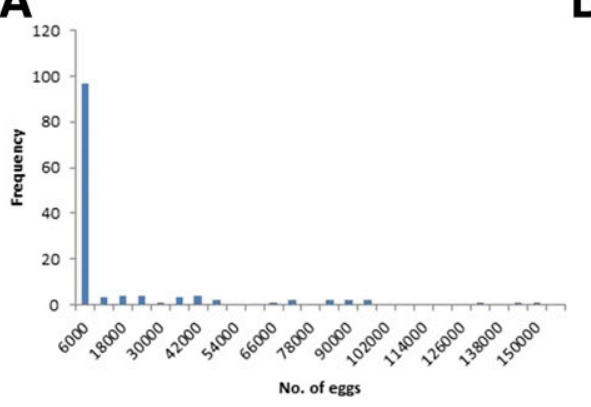

B
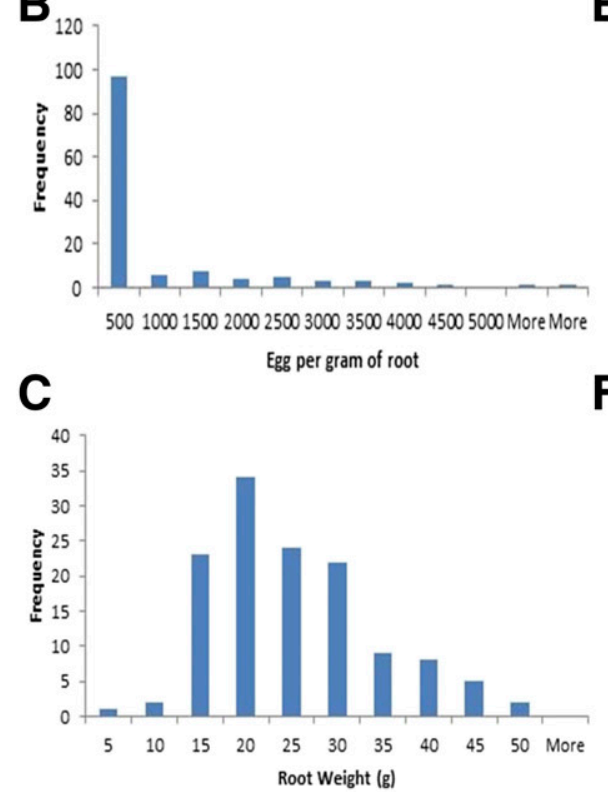

D

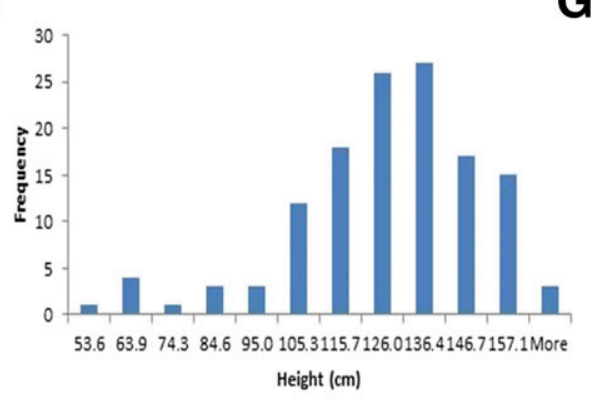

E

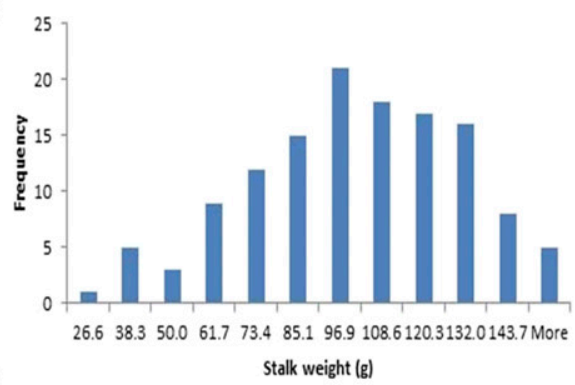

$\mathbf{F}$

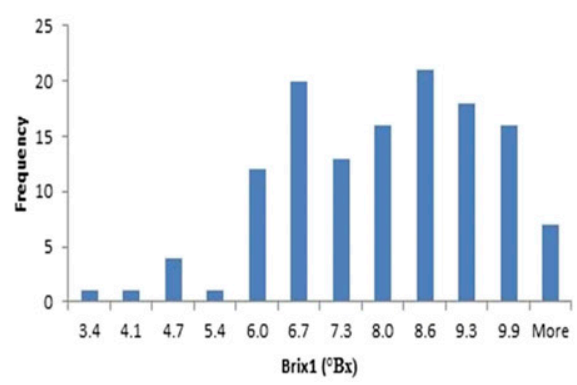

G

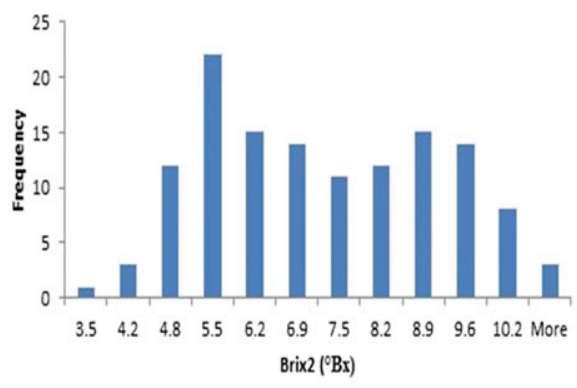

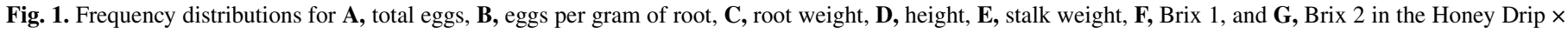
Collier $\mathrm{F}_{2}$ population. 
(average $=107 \mathrm{~g}$ ) and Collier (average $=115 \mathrm{~g}$ ). The average stalk weight for the $F_{1}$ plants was $103 \mathrm{~g}$. The frequency distribution of the $F_{2}$ plants for stalk weight formed a normal distribution (kurtosis $=-0.38$; skewness $=-0.23$ ) suggesting polygenic inheritance (Fig. 1E).

Brix 1 and Brix 2. Using a $t$ test, Brix 1 was significantly different $\left(t=-6.33\right.$, df $\left.=23, P=9.15 \mathrm{E}^{-07}\right)$ between Honey Drip (average $=8.4^{\circ} \mathrm{Bx}$; range 5.3 to $10.6^{\circ} \mathrm{Bx}$ ) and Collier (average $=$ $11.2^{\circ} \mathrm{Bx}$; range 7.6 to $12.4^{\circ} \mathrm{Bx}$ ). Similarly, Brix 2 was significantly different $\left(t=-6.4\right.$, df $\left.=24, P=6.22 \mathrm{E}^{-07}\right)$ between Honey Drip (average $=7.2^{\circ} \mathrm{Bx}$; range 4.3 to $9.7^{\circ} \mathrm{Bx}$ ) and Collier (average $=10.6^{\circ} \mathrm{Bx}$; range 7.6 to $12.6^{\circ} \mathrm{Bx}$ ). The average Brix 1 value and Brix 2 value for the $\mathrm{F}_{1}$ plants was $8.4^{\circ} \mathrm{Bx}$ (range 7.0 to $10.1^{\circ} \mathrm{Bx}$ ) and $7.1^{\circ} \mathrm{Bx}$ (range 4.7 to $9.4^{\circ} \mathrm{Bx}$ ), respectively, suggesting that lower sugar concentration was dominant. The frequency distributions of the $\mathrm{F}_{2}$ plants for both Brix 1 and Brix 2 were bimodal with a large number of progeny having lower Brix than Honey Drip, indicating strong transgressive segregation is occurring in the direction of lower sugar concentration (Fig. 1F and $\mathrm{G}$ ).

Marker by trait association analysis. $G$-model. Using GBS, 4,547 polymorphic SNP markers that were aligned to the physical map were used for marker by trait association analysis for $92 \mathrm{~F}_{2}$ individuals. The G-Model (Bernardo 2013) was used to identify markers that were significantly associated with all seven traits examined. Only three traits had significant markers associated (Table 2). For height, a marker, 01_218939599, on chromosome 3 was identified from Honey Drip that is associated with a reduction in plant height by $14.88 \mathrm{~cm}$. Two and three SNPs, respectively, were associated with $\log _{10}(x+1)$ total eggs and $\log _{10}(x+1)$ eggs per gram of root: SNP marker S1_204738790 on chromosome 3 was associated with a total egg reduction of -1.84 eggs and SNP marker S1_204105631was associated with a reduction in the number of egg per gram of root by 1.37 eggs per gram root (Table 2). In contrast, SNP marker S1_273269722 on chromosome 4 was associated with an increase in total eggs by 0.27 eggs and the amount of egg per gram of root by 0.27 eggs per gram of root compared with Honey Drip (Table 2). Furthermore, SNP S1_645243447 on chromosome 10 was associated with a reduction in the eggs per gram of root by -0.13 .

Single marker analysis. Single marker analysis was used on 90 $\mathrm{F}_{2}$ individuals (two individuals with more than $25 \%$ missing data were excluded) utilizing 3,320 filtered SNPs. Single marker analysis identified a significant QTL (Fig. 2) associated with $\log _{10}(x+1)$ total eggs and $\log _{10}(x+1)$ eggs per gram of root on chromosome 3 that encompasses the same area as the marker that was identified by the G-Model (Table 2). The majority of significant markers ( 278 shared markers) were overlapping between these two traits on chromosome 3 . The SNP marker on chromosome 3 with the highest association for $\log _{10}(x+1)$ total eggs and $\log _{10}(x+1)$ eggs per gram of root was at $53,188,866$ bp $\left(R^{2}=57\right.$ and $64 \%$, respectively).

A significant QTL (Fig. 2) was identified for height and stalk weight on chromosome 3 that colocates with the height-associated marker identified by the G-Model (Table 1). The marker with the strongest association was at $67,516,392 \mathrm{bp}\left(R^{2}=27 \%\right)$. The marker with the highest association with stalk weight on chromosome 3 was at $66,995,801 \mathrm{bp}\left(R^{2}=16 \%\right)$.
Composite interval mapping. Composite interval mapping was performed using 353 SNP markers, forming 19 linkage groups, and four QTL were identified (Tables 3 and 4). Composite interval mapping identified a marker at $51,871,815 \mathrm{bp}$ on chromosome 3 as having the highest LOD for $\log _{10}(x+1)$ total eggs $(57 \%$ of the phenotypic variance) and $\log _{10}(x+1)$ eggs per gram of root $(70 \%$ of the phenotypic variance). A QTL for height was identified at $67,516,392$ bp on chromosome 3 (marker with the highest LOD). A QTL for Brix 2 was identified on chromosome 3 at 68,255,519 bp.

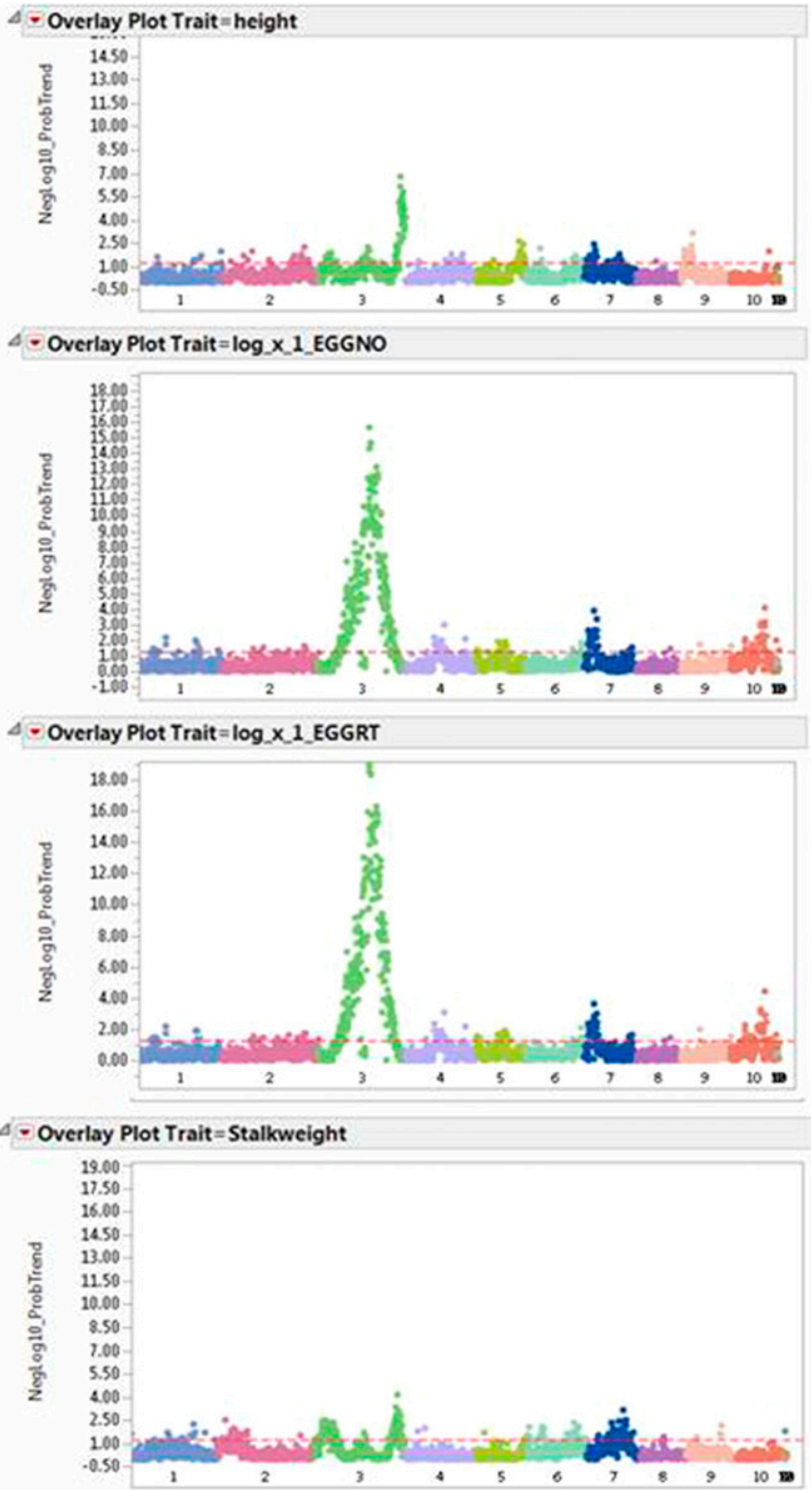

Fig. 2. Manhattan plot of chromosomal regions with significant markers for height, $\log _{10}(x+1)$ total eggs (EGGNO), $\log _{10}(x+1)$ eggs per gram of root (EGGRT), and stalk weight using single marker analysis.

TABLE 2. Single nucleotide polymorphism markers that were significantly associated with height, total eggs, and eggs per gram of root identified from the G-model

\begin{tabular}{lcccc}
\hline Trait & Marker & Chromosome & Position $(\mathrm{bp})$ & Marker effect $^{\mathrm{a}}$ \\
\hline Height & $01 \_218939599$ & 3 & 67516640 & $-14.88 \mathrm{~cm}$ \\
LogEGGNO & S1_204738790 & 3 & 53315831 & -1.84 eggs \\
LogEGGNO & S1_273269722 & 4 & 47438266 & 0.27 eggs \\
LogEGGRT & S1_204105631 & 3 & 52682672 & -1.37 eggs/g of root \\
LogEGGRT & S1_273269722 & 4 & 47438266 & 0.27 eggs/g of root \\
LogEGGRT & S1_645243447 & 10 & 47936400 & -0.13 eggs/g of root \\
\hline
\end{tabular}

${ }^{a}$ Marker effect when comparing the Honey Drip allele to the Collier allele. 
The use of interval mapping (data not shown) identified the same QTL as composite interval mapping at the same locations except the QTL for Brix 2 was not identified.

SSR development for the major root-knot nematode QTL region. Markers on chromosome 3 with the highest association for $\log _{10}(x+1)$ total eggs or $\log _{10}(x+1)$ total eggs per gram of root ranged from $51,871,815$ to $55,320,070$ bp depending on the analysis method used. Four polymorphic SSR markers (Table 5) were designed spanning this chromosome 3 region and were amplified on the Honey Drip $\times$ Collier $F_{2}$ population. SSR marker RKNP709 (Table 5) was difficult to discern and was not scored. Joinmap was used to map the SSR markers with the resistance gene (cutoff for susceptibility was 446 eggs/g of root). The resistance gene mapped between RKNP821 (4.7 cM) and RKNP135 (2.4 cM), which is between $53,190.542$ to $55,784,368$ bp on the sorghum chromosome 3 sequence (NC_012872.1) (Fig. 3; Table 5).

\section{DISCUSSION}

The seven traits measured in the $130 \mathrm{~F}_{2}$ progeny displayed a normal distribution with the exception of total eggs and eggs per gram of root. Many of the traits were strongly correlated (Table 1) such as total eggs and eggs/root $(r=0.94)$, height and stalk weight $(r=0.71)$, and Brix 1 and Brix $2(r=0.87)$. Elangovan et al. (2007) had shown a correlation with stem weight and plant height $(r=0.65)$ in sorghum, and Shen et al. (2006) had seen a strong correlation $(r=$ 0.91 ) between $M$. incognita total eggs and eggs per gram of root in cotton. Traits with moderate correlations such as plant height and Brix (Ritter et al. 2008) and Brix and stalk weight $(r=0.37)$ (Murray et al. 2008) had been seen previously in sweet sorghum. In contrast, the positive correlations between root weight and Brix $(r=0.50$ for Brix 1 and 0.45 for Brix 2) and between root weight and stalk weight ( $r=0.63)$ had not been previously associated in sorghum likely because it is rare to sample root weight when measuring Brix and stalk weight.
The $\mathrm{F}_{2}$ segregation ratios (Fig. 1A and B) and the four QTL methods used support that a major dominant gene from Honey Drip on chromosome 3 restricts total eggs and eggs per gram of root. Resistance to plant-parasitic nematodes is often controlled by only one or a few genes (Cai et al. 1997; Milligan et al. 1998; van der Vossen et al. 2000). Dominant genes for nematode resistance have been observed in other crops including cotton (McPherson et al. 2004), tomato (Milligan et al. 1998), peach (Prunus persica (L.) Batsch) (Lu et al. 2000), and peanut (Arachis spp.) (Garcia et al. 1996).

The location of the QTL for total eggs and eggs per gram of root had a peak LOD from $51,871,815$ to $55,320,070 \mathrm{bp}$ on chromosome 3 using the G-Model, single marker analysis, interval mapping, and composite interval mapping. It is reported that composite interval mapping is hampered by selective genotyping (Alonso-Blanco et al. 2006) but some studies show that selective genotyping is appropriate for use with composite interval mapping (Service 2013). Here, the use of composite interval mapping identified the same QTL as interval mapping and identified an additional QTL for Brix 2. Examination of the sequence containing the total eggs and eggs per gram of root QTL interval (Table 4) on chromosome 3 using Phytozome v 10.1 identified 17 leucine rich repeat (LRR) receptor-like protein kinases and three genes that contain an LRR domain that may be the candidate gene. In tomato, silencing LRR

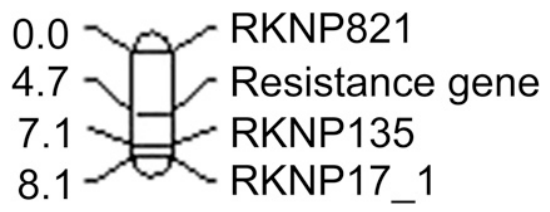

Fig. 3. In a 'Honey Drip' $x$ 'Collier' $F_{2}$ population, map order on sorghum chromosome 3 of the root-knot nematode resistance gene and the sorghum simple sequence repeat markers.

TABLE 3. Additive, dominance, and phenotypic variance of each quantitative trait loci identified by composite interval mapping

\begin{tabular}{llcccc}
\hline Marker $^{\mathrm{a}}$ & QTL & Additive $^{\mathrm{b}}$ & Dominance $^{\mathrm{c}}$ & D/A & Phenotypic variance (\%) \\
\hline 1591 & LogEGGNO & 1.63 & -0.60 & -0.37 & 57 \\
1591 & LogEGGRT & 1.29 & -0.54 & -0.42 & 70 \\
1810 & Height & 15.16 & 5.67 & 0.37 & 34 \\
1822 & Brix 2 & 0.76 & 0.76 & 1 & 19 \\
\hline
\end{tabular}

a Marker with the highest LOD score in the QTL peak.

$\mathrm{b}$ The sign of the estimated additive effects is associated with the allele from Collier.

c The sign associated with estimated dominance effects indicates the effect of the allele from Collier for the heterozygous condition.

TABLE 4. Quantitative trait loci regions on chromosome 3 identified by composite interval mapping

\begin{tabular}{lcrrr}
\hline Trait & Marker with highest LOD & LOD & Marker interval & Interval (bp) \\
\hline logEGGNO & $1591(51,871,815 \mathrm{bp})$ & 16.6 & $1574-1630$ & $45,631,816-54,974,726$ \\
logEGGRT & $1591(51,871,815 \mathrm{bp})$ & 23.6 & $1574-1630$ & $1791-1822$ \\
Height & $1810(67,516,392 \mathrm{bp})$ & 8.1 & $1810-1823$ & $64,531,816-54,974,726$ \\
Brix 2 & $1822(68,255,519 \mathrm{bp})$ & 4.2 & $67,516-68,255,519$ \\
\hline
\end{tabular}

TABLE 5. Polymorphic simple sequence repeat markers designed in the major quantitative trait loci region, on sorghum chromosome 3, associated with a reduction in total root-knot nematode eggs and eggs per gram of root in Honey Drip

\begin{tabular}{|c|c|c|c|}
\hline Marker name & Motif & Chr 3 position (bp) ${ }^{\mathrm{a}}$ & Primer sequence $\left(5^{\prime}-3^{\prime}\right)$ \\
\hline RKNP17_F & (TTA) 106 & $52,744,750$ & GCAGTTTTTCAAGGAACGTG \\
\hline RKNP17_R & & & GAGGAATGGGTGATGAAACAA \\
\hline RKNP135_F & $(\mathrm{AAG}) 21$ & $53,190,542$ & GTTTCGTTTCAATCGGCTTC \\
\hline RKNP709_F & $(\mathrm{CT}) 9+(\mathrm{TA}) 18$ & $55,360,265$ & GCAAGCTGAAGTGGCCTAGT \\
\hline RKNP709_R & & & CTACTCCCTCCGTCCCAAAT \\
\hline RKNP821_F & (TA) 51 & $55,784,368$ & CTCGGCAGCACCAAATAAAA \\
\hline RKNP821R & & & TCTCAACCGATGATTGTCCA \\
\hline
\end{tabular}

a Position on sorghum chromosome 3 (NC_012872.1). 
receptor-like kinases SISERK3A and/or SISERK3B resulted in enhanced susceptibility to root-knot nematodes (Peng and Kaloshian 2014). Furthermore, genes that encode proteins containing a LRR domain have been shown to confer nematode resistance in other plant species, including a nucleotide biding site (NBS)LRR protein encoded by $M i$ for $M$. arenaria (Neal) Chitwood, $M$. incognita, and $M$. javanica (Treub) Chitwood in tomato (Milligan et al. 1998), a protein containing a leucine rich region at its amino terminus encoded by $\mathrm{Hs} 1^{\text {Pro-1 }}$ for the beet cyst nematode in sugar beet (Cai et al. 1997), a NBS-LRR protein encoded by XiRl for dagger nematode resistance in grape (Vitis spp.) (Hwang et al. 2010), and an NBS-LRR encoded by Cre3 in wheat (Triticum aestivum L.) against Heterodera avenae Woll. (Lagudah et al. 1997). Further fine-mapping of the QTL identified in this study, $Q T L-S b . R K N .3 .1$, here named, should help elucidate the causal variant for root-knot nematode resistance in sorghum.

This study provides SSR markers (Fig. 3), a type of marker that can be readily utilized by many throughout the world, that are linked to the major resistance gene in $Q T L-S b . R K N .3 .1$, which restricts total eggs and eggs per gram of root. These markers can be utilized to move this region from Honey Drip to any fertile sorghum line using marker-assisted selection. In crop rotation, the use of rootknot nematode resistant sorghum could keep root-knot nematode populations low for the next susceptible crop grown.

A novel QTL for height on chromosome 3 was identified from the Honey Drip $\times$ Collier $F_{2}$ population using the G-Model, single marker analysis, interval mapping, and composite interval mapping (Fig. 2; Tables 2, 3, and 4). Plant height in sorghum is controlled by maturity genes which determine the number of internodes and dwarfing genes which control the internode lengths (Brown and Paterson, 2013). The cloned maturity genes SbPRR37 (Mal) (Murphy et al. 2011) and SbGHD7 (Ma6) (Murphy et al. 2014) are both on chromosome 6, while phytochrome B (Ma3) (Childs et al. 1997) and Ma5 (Kim 2003) are on chromosomes 1 and 2, respectively. Ma4 is located on chromosome 10 (Hart et al. 2001). The dwarfing genes Dw3 (Multani et al. 2003) and Dw2 (Lin et al. 1995) are on chromosomes 7 and 6, respectively. A QTL that controls height, Sb.Ht9.1 (Brown et al. 2008), is on chromosome 9. Higgins (2013) had identified a height QTL on chromosome 3, but in a different location as the QTL identified in this study. This newly identified plant height QTL may be specific to sweet sorghum and was given the name $Q T L-S b$.Ht3.2. Using the Phytozome v. 10.1 sequence, many proteins are in this area, such as two auxin responsive proteins and two proteins with an APETALA2 domain, but no obvious candidate could be identified.

In conclusion, using GBS and QTL mapping a single QTL was identified that controls total eggs and eggs per gram of root on chromosome 3. SSR markers were developed in this region and can be used for marker-assisted selection. Additionally, a new QTL for plant height was also identified on chromosome 3 .

\section{ACKNOWLEDGMENTS}

We thank D. Boykin, N. Flader, D. Bunphan, D. Clements, S. Pelc, S. Drawdy, and the anonymous reviewers for their reviews and technical help. This project was funded by the USDA-ARS.

\section{LITERATURE CITED}

Alonso-Blanco, C., Koornneef, M., and van Ooijen, J. W. 2006. QTL analysis. Pages 79-99 in: Arabidopsis Protocols. Methods in Molecular Biology. 2nd ed. J. Salinas and J. J. Sanchez-Serrano, eds. Springer, New York.

Bernardo, R. 2013. Genome-wide markers for controlling background variation in association mapping. Plant Genome 6:1-9.

Blasingame, D., and Patel, M. V. 2013. Cotton disease loss estimate committee report. Pages 1242-1246 in: Proc. Beltwide Cotton Conf., Natl. Cotton Counc. Am., Memphis, TN.

Brown, P. J., and Paterson, A. 2013. Genomics of the Saccharinae, 1st ed. Springer-Verlag, New York.
Brown, P. J., Rooney, W. L., Franks, C., and Kresovich, S. 2008. Efficient mapping of plant height quantitative trait loci in a sorghum association population with introgressed dwarfing genes. Genetics 180:629-637.

Cai, D., Kleine, M., Kifle, S., Harloff, H. J., Sandal, N. N., Marcker, K. A., Klein-Lankhorst, R. M., Salentijn, E. M. J., Lange, W., Stiekema, W. J., Wyss, U., Grundler, F. M. W., and Jung, C. 1997. Positional cloning of a gene for nematode resistance in sugar beet. Science 275:832-834.

Casa, A. M., Pressoir, G., Brown, P. J., Mitchell, S. E., Rooney, W. L., and Tuinstra, M. R. 2008. Community resources and strategies for association mapping in sorghum. Crop Sci. 48:30-40.

Childs, K. L., Miller, F. R., Cordonnier-Pratt, M. M., Pratt, L. H., Morgan, P. W., and Mullet, J. E. 1997. The sorghum photoperiod sensitivity gene, $\mathrm{Ma}_{3}$, encodes a phytochrome B. Plant Physiol. 113:611-619.

Dancey, C. P., and Reidy, J. 2004. Statistics Without Maths for Psychology: Using SPSS for Windows, 3rd ed. Pearson, Prentice Hall, New York.

Davis, R. F. 2007. Effect of Meloidogyne incognita on watermelon yield. Nematropica 37:287-293.

Davis, R. F., and Anderson, W. F. 2012. Identification of widely varying levels of resistance to Meloidogyne incognita in sweet sorghum. J. Nematol. 44: 475.

Davis, R. F., and Timper, P. 2000. Resistance in selected corn hybrids to Meloidogyne arenaria and M. incognita. J. Nematol. 32:633-640.

Elangovan, M., Prabhakar, and Reddy, D. C. S. 2007. Characterization and evaluation of sorghum [Sorghum bicolor (L.) Moench] germplasm from Karnataka, India. Karnataka J. Agric. Sci. 20:840-842.

Elshire, R. J., Glaubitz, J. C., Sun, Q., Poland, J. A., Kawamoto, K., Buckler, E. S., and Mitchell, S. E. 2011. A robust, simple genotyping-by-sequencing (GBS) approach for high diversity species. PLoS One 6:e19379.

Garcia, G. M., Stalker, H. T., Shroeder, E., and Kochert, G. 1996. Identification of RAPD, SCAR, and RFLP markers tightly linked to nematode resistance genes introgressed from Arachis cardenasii into Arachis hypogaea. Genome 39:836-845.

Goodstein, D. M., Shu, S., Howson, R., Neupane, R., Hayes, R. D., and Fazo, J. 2012. Phytozome: A comparative platform for green plant genomics. Nucleic Acids Res. 40:D1178-D1186.

Harris-Shultz, K., Harrison, M., Wadl, P. A., Trigiano, R. N., and Rinehart, T. 2015. Development and characterization of microsatellite markers for a little bluestem collection. J. Am. Soc. Hortic. Sci. 140:78-87.

Hart, G. E., Schertz, K. F., Peng, Y., and Syed, N. H. 2001. Genetic mapping of Sorghum bicolor (L.) Moench QTLs that control variation in tillering and other morphological characters. Theor. Appl. Genet. 103:1232-1242.

Herman, M., Hussey, R. S., and Boerma, H. R. 1991. Penetration and development of Meloidogyne incognita on roots of resistant soybean genotypes. J. Nematol. 23:155-161.

Higgins, R. H. 2013. Genetic dissection of sorghum height and maturity variation using sorghum converted lines and their exotic progenitors. Master's thesis. University of Illinois at Urbana-Champaign.

Hussain, M. A., Mukhtar, T., and Kayani, M. Z. 2011. Assessment of the damage caused by Moloidogyne incognita on okra (Abelmoschus esculentus). J. Anim. Plant Sci. 21:857-861.

Hussey, R. S., and Barker, K. R. 1973. A comparison of methods of collecting inocula for Meloidogyne spp., including a new technique. Plant Dis. Rep. 57:1025-1028.

Hwang, C. F., Xu, K., Hu, R., Zhou, R., Riaz, S., and Walker, M. A. 2010. Cloning and characterization of XiR1, a locus responsible for dagger nematode resistance in grape. Theor. Appl. Genet. 121:789-799.

Jacquet, M., Bongiovanni, M., Martinez, M., Verschave, P., Eajnberg, E., and Catagnone-Sereno, P. 2005. Variation in resistance to the root-knot nematode Meloidogyne incognita in tomato genotypes bearing the Mi gene. Plant Pathol. 54:93-99.

Kim, J. S. 2003. Genomic analysis of sorghum by fluorescence in situ hybridization. Ph.D. dissert. Texas A\&M University.

Lagudah, E. S., Moullet, O., and Appels, R. 1997. Map-based cloning of a gene sequence encoding a nucleotide-binding domain and leucine-rich region at the Cre3 nematode resistance locus of wheat. Genome 40:659-665.

Lin, Y. R., Schertz, K. F., and Paterson, A. H. 1995. Comparative analysis of QTLs affecting plant height and maturity across the Poaceae, in reference to an interspecific sorghum population. Genetics 141:391-411.

Lu, Z., Reighard, G. L., Nyczepir, A. P., Beckman, T. G., and Ramming, D. W. 2000. Inheritance of resistance to root-knot nematodes (Meloidogyne sp.) in Prunus rootstocks. HortScience 35:1344-1346.

McClure, M., Husman, S., and Schmitt, M. 1998. Page 8572 in: Cotton: A College of Agriculture Report. College of Agriculture, The University of Arizona, Tucson, AZ.

McPherson, M. G., Jenkins, J. N., Watson, C. E., and McCarty, J. C. 2004. Inheritance of root-knot nematode resistance in M-315 RNR and M78-RNR cotton. J. Cotton Sci. 8:154-161.

McSorley, R., and Gallaher, R. N. 1993. Population densities of root-knot nematodes following corn and sorghum in cropping systems. Pages 26-29 
in: Southern Conserv. Tillage Conf. for Sustainable Agriculture. P. K. Bollich, ed. Proc. Agric. Exp. Stn. 93-86-7122.

Milligan, S. B., Bodeau, J., Yagjoobi, J., Kaloshian, I., Zabel, P., and Williamson, V. M. 1998. The root knot nematode resistance gene $M i$ from tomato is a member of the leucine zipper, nucleotide binding, leucine-rich repeat family of plant genes. Plant Cell 10:1307-1319.

Multani, D. S., Briggs, S. P., Chamberlin, M. A., Blakeslee, J. J., Murphy, A. S., and Johal, G. S. 2003. Loss of an MDR transporter in compact stalks of maize $b r 2$ and sorghum $d w 3$ mutants. Science 302:81-84.

Murphy, R. L., Klein, R. R., Morishige, D. T., Brady, J. A., Rooney, W. L., and Miller, F. R. 2011. Coincident light and clock regulation of pseudoresponse regulator protein 37 (PRR37) controls photoperiodic flowering in sorghum. PNAS 108:16469-16474.

Murphy, R. L., Morishige, D. T., and Brady, J. A. 2014. Ghd7 $\left(\mathrm{Ma}_{6}\right)$ represses sorghum flowering in long days: Ghd7 alleles enhance biomass accumulation and grain production. Plant Genome 7:1-10.

Murray, S. C., Rooney, W. L., Hamblin, M. T., Mitchell, S. E., and Kresovich, S. 2009. Sweet sorghum genetic diversity and association mapping for brix and height. Plant Genome 2:48-62.

Murray, S. C., Sharma, A., Rooney, W. L., Klein, P. E., Mullet, J. E., and Mitchell, S. E. 2008. Genetic improvement of sorghum as a biofuel feedstock: I. QTL for stem sugar and grain nonstructural carbohydrates. Crop Sci. 48:2165-2179.

Peng, H.-C., and Kaloshian, I. 2014. The tomato leucine-rich repeat receptorlike kinases SISERK3A and SISERK3B have overlapping functions in bacterial and nematode innate immunity. PLoS One 9:e93302.

Ploeg, A. T., and Phillips, M. S. 2001. Damage to melon (Cucumis melo L.) cv. Durango by Meloidogyne incognita in southern California. Nematology 3: $151-157$

Ritter, K. B., Jordan, D. R., Chapman, S. C., Godwin, I. D., Mace, E., and McIntyre, C. L. 2008. Identification of QTL for sugar-related traits in a sweet $\times$ grain sorghum (Sorghum bicolor L. Moench) recombinant inbred population. Mol. Breed. 22:367-384.
Rosskopf, E. N., Chellemi, D. O., Kokalis-Burelle, N., and Church, G. T. 2005. Alternatives to methyl bromide: A Florida perspective. APSnet Features. The American Phytopathological Society, St. Paul, MN.

Rozen, S., and Skaletsky, H. J. 1998. Primer3. 2015. http://www-genome.wi. mit.edu/genome_software/other/primer3.html

Service, P. M. 2013. Honesty, power and bootstrapping in composite interval quantitative trait locus mapping. Open J. Genet. 3:127-140.

Shen, X., Becelaere, G. V., Kumar, P., Davis, R. F., May, O. L., and Chee, P. 2006. QTL mapping for resistance to root-knot nematodes in the M-120 RNR Upland cotton line (Gossypium hirsutum L.) of the Auburn 623 RNR source. Theor. Appl. Genet. 113:1539-1549.

Temnykh, S., DeClerck, G., Lukashova, A., Lipovich, L., Cartinhour, S., and McCouch, S. 2001. Computational and experimental analysis of microsatellites in rice (Oryza sativa L.): Frequency, length variation, transposon association, and genetic marker potential. Genome Res. 11:1441-1452.

Thies, J. A. 2011. Virulence of Meloidogyne incognita to expression of $\mathrm{N}$ gene in pepper. J. Nematol. 43:90-94.

Trudgill, D. L., and Blok, V. C. 2001. Apomictic, polyphagous root-knot nematodes: Exceptionally successful and damaging biotrophic root pathogens. Annu. Rev. Phytopathol. 39:53-77.

van der Vossen, E. A., van der Voort, J. N., Kanyuka, K., Bendahmane, A., Sandbrink, H., and Baulcombe, D. C. 2000. Homologues of a single resistance-gene cluster in potato confer resistance to distinct pathogens: a virus and a nematode. Plant J. 23:567-76.

Weiland, J. J., and Yu, M. H. 2003. A cleaved amplified polymorphic sequence (CAPS) marker associated with root-knot nematode resistance in sugarbeet. Crop Sci. 43:1814-1818.

Windham, G. L. 1998. Corn. Pages 335-357 in: Plant Nematode Interactions. K. R. Barker, G. A. Pederson, and G. L. Windham, eds. American Society of Agronomy, Madison, WI.

Zasada, I. A., Halbrendt, J. M., Kokalis-Burelle, N., LaMondia, J., McKenry, M. V., and Noling, J. W. 2010. Managing nematodes without methyl bromide. Annu. Rev. Phytopathol. 48:311-328. 